\title{
Sweet Lime-Mediated Decolorization of Textile Industry Effluents
}

\author{
Shazia Nouren ${ }^{*}$, Masood Sarwar², Ghulam Muhi-ud-Din ${ }^{3}$, Muhammad Yameen ${ }^{4}$, \\ Haq Nawaz Bhatti ${ }^{3}$, Gul Afshan Soomro5, Muhammed Suleman ${ }^{6}$, Ismat Bibi ${ }^{7}$, \\ Abida Kausar ${ }^{8}$, Arif Nazir ${ }^{9 *}$, Munawar Iqbal ${ }^{9}$ \\ ${ }^{1}$ Department of Chemistry, Govt. College Women University, Sialkot, Pakistan \\ ${ }^{2}$ Govt. Islamia Degree College Sambrial, Sialkot, Pakistan \\ ${ }^{3}$ Department of Chemistry, University of Agriculture, Faisalabad, Pakistan \\ ${ }^{4}$ Department of Biochemistry, Government College University, Faisalabad, Pakistan \\ ${ }^{5}$ Institute of Chemistry, Shah Abdul Latif University, Khairpur, Sindh, Pakistan \\ ${ }^{6}$ Department of Chemistry, Women University of Azad Jammu and Kashmir, Bagh, Pakistan \\ ${ }^{7}$ Department of Chemistry, Islamia University Bahawalpur, Pakistan \\ ${ }^{8}$ Department of Chemistry, Govt. College Women University, Faisalabad, Pakistan \\ ${ }^{9}$ Department of Chemistry, The University of Lahore, Lahore, Pakistan
}

Received: 11 October 2017

Accepted: 8 December 2017

\begin{abstract}
This study looks at using partially purified peroxidase extracted from peels of sweet lime (Citrus limetta) for decolorizing textile industry effluent. The ideal $\mathrm{pH}$ and thermal conditions of the enzyme were 7 and $35^{\circ} \mathrm{C}$. The $K_{m}$ and $V_{\text {max }}$ for guaiacol were $0.66 \mathrm{mM}$ and $6666 \mu \mathrm{mol} / \mathrm{mL} / \mathrm{min}$, respectively. We found that sweet lime peroxidase was very effective in decolorizing textile industry effluent. Almost complete decolorization ( $>99 \%$ ) of effluent was attained at a $\mathrm{pH}$ of 5.0, temperature of $55^{\circ} \mathrm{C}, \mathrm{H}_{2} \mathrm{O}_{2}$ concentration of $2 \mathrm{mM}$, and enzyme dose of $40 \mathrm{U} / \mathrm{mL}$ within 60 minutes of incubation. The effluent was also analysed in terms of physicochemical parameters before and after treatment with sweet lime peroxidase. The reduction in toxicity after the enzymatic treatment was evidenced by chemical oxygen demand (COD) and total suspended solids (TSS) values.
\end{abstract}

Keywords: peroxidase, sweet lime, decolorization, $K_{m}, V_{\max }$, effluents

\section{Introduction}

Rapid increases in world population, urbanization, and other activities of industrialization have led to extensive applications of chemicals such as dyes in our daily life. A major source of these dyes are our textile

*e-mail: anmalik77@gmail.com industries that utilize them extensively and possess a major threat to the environment by releasing a significant portion via wastewater. It is estimated that $>10,000$ dyes and pigments are utilized and more than 0.7 million tons of dyes of synthetic origin are produced annually [1-2]. Dye removal from industrial effluents is a concern, and the variety of physical, chemical, and biological techniques have been developed [3]. Traditionally it has been done by applying various processes like adsorption, 
ozonation, $\mathrm{UV} / \mathrm{NaOCl}$, electrochemical oxidation, ultrasonic irradiation, the photo-Fenton process, and $\mathrm{UV} / \mathrm{H}_{2} \mathrm{O}_{2}$ [4-18]. These methods are not considered as effective due to overuse of various toxic chemicals that cause many environmental issues (although an ecofriendly technique like biological decolorization could be used as best alternative). These enzyme-based methods applied in dye degradation are cost-effective, easily controllable, and eco-friendly. In this regard, peroxidases (PODs) belonging to the class of oxidoreductases are considered very important [19].

PODs are the enzymes that are widely found in plants, microorganisms, and vertebrates. These are categorized as: prokaryotic and plant intracellular enzymes, extracellular fungal PODs, and higher plants PODs [20]. These PODs are single-chain proteins having multiple isomers and may differ in function, substrate specificity, or $\mathrm{pH}$ [21]. Owing to enzymatic activity, stability, and the variety of industrial and environmental applications, higher plant PODs have been deeply studied [22-23].

PODs extracted from different sources have been utilized for degradation of dyes, including horseradish peroxidase [24-27], soybean peroxidase [28], Cucurbita pepo [29], and white Spanish broom [30].

Most recent research is concerned with finding economical ways to treat dye-contaminated effluents. So in the current project an attempt has been made using somewhat purified POD extracted from sweet lime peels (Citrus limetta) to decolorize industrial effluent. The conventional methodology of one variable at a time (OVAT) is well accepted and is utilized in this study.

\section{Material and Methods}

All the chemicals used in this work were of analytical grade and purchased from Sigma-Aldrich Chemical Co. (USA). Isolation and partial purification was done following the method described in Nouren et al. [31]. Enzyme protein contents were determined with bovine serum albumin (BSA) as the standard protein [32].

POD activity was determined with slight modification in the earlier reported assay method [33]. The optimum $\mathrm{pH}$ for POD activity was determined by monitoring the activity of the enzyme as in the assay section using the following buffers: glycine $\mathrm{HCL}(\mathrm{pH} 2.0-4.0)$, acetate $(\mathrm{pH}$ 5.0, 6.0), phosphate $(\mathrm{pH} 7.0,8.0)$, and tris-HCl $(\mathrm{pH}$ 9.0). The optimal temperature was determined by assaying for the activity of the enzyme as in the assay section at different temperatures $\left(25-60^{\circ} \mathrm{C}\right)$. The $K_{m}$ and $V_{\max }$ for guaiacol for sweet lime peroxidase were determined by taking different concentrations of guaiacol $(0.5-45 \mathrm{mM})$ and following the assay for the activity of peroxidase as described in the assay section. The average of the data generated from the assay was used to construct the Line Weaver-Burk plot from which $K_{m}$ and $V_{\max }$ were determined for guaiacol.
SLP was applied to check the decolorization of effluent collected from Arzoo Textile Industry of Faisalabad. It was centrifuged at $10,000 \mathrm{~g}$ for $15 \mathrm{~min}$ and supernatant diluted to 50 times with distilled water in order to get its absorbance within range of the spectrophotometer. Then the $\lambda_{\max }$ was scanned using a Cecil 7200 spectrophotometer and found to be $574.5 \mathrm{~nm}$. The physicochemical parameters were estimated according to the methods prescribed in APHA [34].

The following parameters were optimized for decolorization of the effluent: optimum $\mathrm{pH}$ for decolorization of sweet lime peroxidase catalyzed textile effluent was monitored by using $375 \mu \mathrm{L}$ of buffers $(50 \mathrm{mM})$ of different $\mathrm{pH}$ ranging from $2-10$ with $12 \mathrm{U} / \mathrm{mL}$ of SLP, and $0.25 \mathrm{mM} \mathrm{H}_{2} \mathrm{O}_{2}(375 \mu \mathrm{L})$ at $40^{\circ} \mathrm{C}$ for $30 \mathrm{~min}$. The absorbance was noted at $574.5 \mathrm{~nm}$ [35].

A similar series of experiments were performed through OVAT in order to optimize parameters like temperature $\left(25-70^{\circ} \mathrm{C}\right)$, enzyme dose $(5.0-50.0 \mathrm{U} / \mathrm{mL})$, and $\mathrm{H}_{2} \mathrm{O}_{2}$ concentration $(0.5-10 \mathrm{mM})$. In the end, incubation time (5-240 $\mathrm{min})$ was determined. After heating for $10 \mathrm{~min}$ the reaction was stopped, insoluble product was removed by centrifugation, and a decrease in absorbance was noted at specific $\lambda_{\max }$ of each effluent. Effluent decolorization was calculated as:

$$
\text { Decolorization }(\%)=\left(\mathrm{A}_{0}-\mathrm{A}_{\mathrm{t}} / \mathrm{A}_{0}\right) * 100
$$

...where $A_{0}$ is the absorbance of the untreated effluent and $A_{t}$ is the absorbance of the treated effluent.

\section{Results and Discussion}

\section{Isolation and Partial Purification of SLP}

PODs from peels of sweet lime (SLP) were isolated with $0.1 \mathrm{M}$ phosphate buffer ( $\mathrm{pH}$ 7.0) using a blender with short intermissions. The enzyme assay was performed and specific activity of crude SLP was recorded to be $443.75 \mathrm{U} / \mathrm{mg}$ of the protein. Then the crude enzyme was partially purified by $80 \%$ ammonium sulphate precipitation and then centrifuged. The residue was dissolved in $90 \mathrm{~mL}$ of $0.1 \mathrm{M}$ phosphate buffer $(\mathrm{pH} 7.0)$ and then subjected to dialysis. The process of dialysis was conducted using dialysis tubing within 8 h by 5-6 changes of $25 \mathrm{mM}$ phosphate buffer ( $\mathrm{pH} 7.0$ ). After performing a partial purification step, the specific activity of SLP increased to $2,819.71 \mathrm{U} / \mathrm{mg}$ of protein with 6.35 -fold purification. In previous literature, after ammonium sulphate fractionation 4.8-fold purification was obtained in the case of peroxidase extracted from peel of Citrus jumbhiri with an increase in specific activity from 751 to $2,925 \mathrm{U} / \mathrm{mg}$ [36], while in the case of peroxidase extracted from tubers of Jerusalem artichoke, 2.49-fold purification was attained after dialysis step with an increase in specific activity from 246.2 to $612.1 \mathrm{EU} / \mathrm{mg}$ [37]. 


\section{Characterizing SLP}

Various kinetic and thermodynamic parameters were employed for SLP characterization. The effect of $\mathrm{pH}$ on activity of SLP was determined by assaying the enzyme using buffers of different $\mathrm{pH}$ (2-9) and the result is shown in Fig. 1. It is apparent from Fig. 1 that SLP showed maximum activity at $\mathrm{pH}$ 7.0. There was a gradual decrease in activity with increasing $\mathrm{pH}$ from 8.0-9.0. The optimum activity at $\mathrm{pH} 7.0$ shows that POD has better function in a neutral environment. The heme binding to the active site of enzyme was most stable at neutral $\mathrm{pH}$ [38]. Furthermore, $\mathrm{pH}$ change affects the dissociation of amino acids involved in substrate binding and enzyme catalysis. Therefore, optimal $\mathrm{pH}$ is needed for proper working of a biocatalyst.

Neutral $\mathrm{pH}$ was also reported as optimum in the previous literature for PODs extracted from two Salvia species viz., S. virgata Jacq and $S$. viridis $L$. using guaiacol as substrate. It was also revealed that activities of the PODs were also dependent on the concentrations of the buffers as well as the substrate used. The same optimum was also achieved for Olea europaea peroxidase [39] and horseradish peroxidase [40]. The temperature-activity profile of SLP is shown in Fig. 1 , which shows that the optimum temperature for the activity of SLP was $35^{\circ} \mathrm{C}$ and beyond, in which a decrease in activity took place, indicating low themostability. A wide variability regarding optimum temperature of peroxidase has been noticed from diverse sources. For example, PODs extracted from vanilla bean [41], cauliflower [42], A. sativum [43-44], and Citrus jambherri peel [22] showed optima at 16, 30, 35, and $40^{\circ} \mathrm{C}$, respectively.
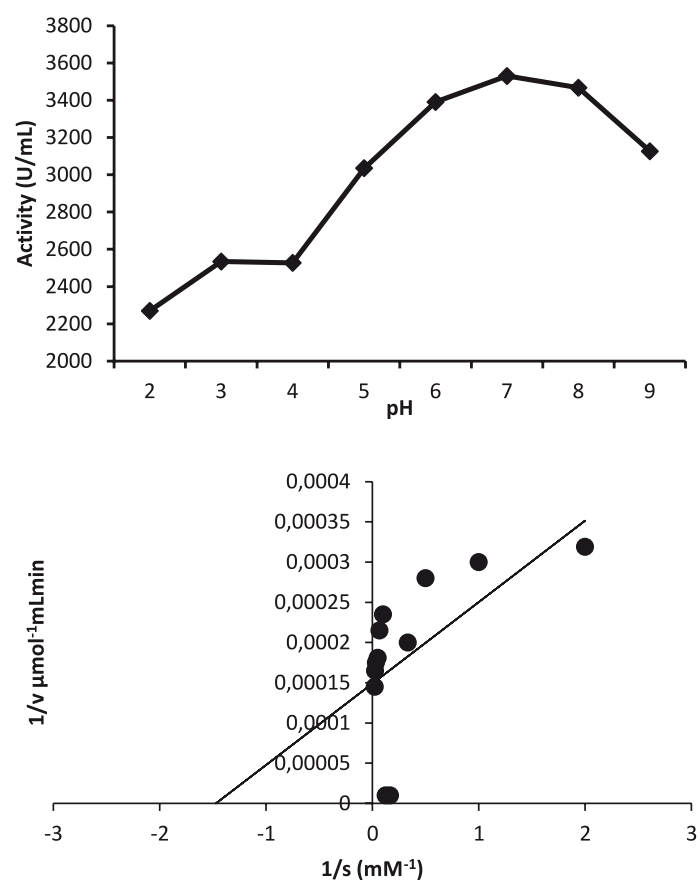

In order to determine the effect of substrate concentration and kinetic parameters, substrate specificity $\left(K_{m}\right.$ and $\left.V_{m a x}\right)$ values for guaiacol were determined by Line Weaver-Burk plot. The effect of guaiacol on POD activity was determined by varying the concentration of guaiacol, keeping a fixed concentration of the second substrate of $\mathrm{H}_{2} \mathrm{O}_{2}$.

The $K_{m}$ and $V_{\max }$ values for SLP were calculated respectively from Fig. 1. It is obvious from the data that $K_{m}$ value for SLP was reported to be $0.66 \mathrm{mM}$ with corresponding $V_{\max }$ value of $6666 \mu \mathrm{mol} / \mathrm{mL} / \mathrm{min}$. The lower value of $K_{m}$ for SLP depicted its higher affinity for guaiacol.

PODs have different $K_{m}$ and $V_{\max }$ depending upon sources, e.g., in the case of Citrus jambherri peel POII [22], Turkish black radish [45], and horseradish cv. Balady [27], $K_{m}$ values of 5, 0.036, and $16.4 \mathrm{mM}$ with corresponding $V_{\max }$ values of $18,38,728.17$, and $0.71 \mu \mathrm{mol} / \mathrm{mL} / \mathrm{min}$ were respectively found for guaiacol as substrate.

\section{Physicochemical Portrayal of Textile Runoff}

Textile industry runoff was characterized before and after treatment with SLP for different physicochemical parameters, the values of these parameters are presented in Table 1. $\mathrm{pH}$ is one of the parameters for assessing water quality. Generally, water having $\mathrm{pH}$ $<6.5$ and $>8.5$ is not recommended for public consumption. In our study, $\mathrm{pH}$ is changed from 6.5 to 7.5. Electrical conductivity is changed from 3.31 to 2.98. The results indicate an almost $50 \%$ decrease in chemical oxygen demand and almost $11 \%$ decrease in total dissolved solids after the treatment of textile runoff
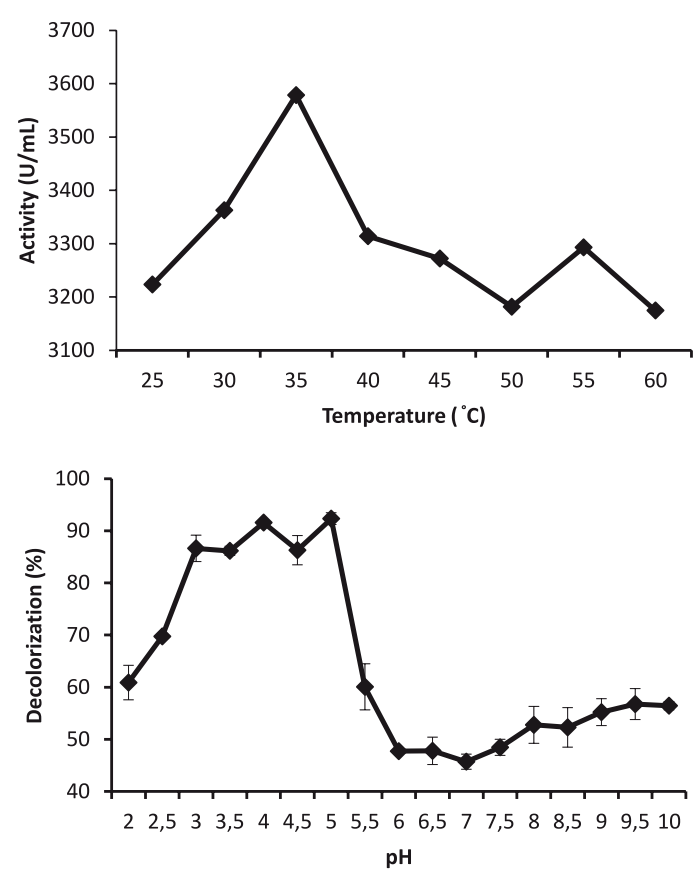

Fig. 1. Effects of $\mathrm{pH}$, temperature, and guaiacol concentration on the activity of SLP and effect of $\mathrm{pH}$ on percentage decolorization. 
Table 1. Physicochemical characterization of textile effluents.

\begin{tabular}{|c|c|c|}
\hline $\begin{array}{c}\text { Physicochemical } \\
\text { parameter }\end{array}$ & Before treatment & $\begin{array}{c}\text { After treatment } \\
\text { with SLP }\end{array}$ \\
\hline $\mathrm{pH}$ & 6.7 & 7.5 \\
\hline $\mathrm{EC}(\mathrm{mS} / \mathrm{cm})$ & $3.31 \pm 0.1655$ & $2.98 \pm 0.149$ \\
\hline $\mathrm{TDS}(\mathrm{mg} / \mathrm{L})$ & $1550 \pm 69.75$ & $1380 \pm 62.10$ \\
\hline $\mathrm{COD}(\mathrm{mg} / \mathrm{L})$ & $211 \pm 11.605$ & $106 \pm 5.83$ \\
\hline
\end{tabular}

with SLP, indicating that enzymatic treatment is an effective method for the cause.

\section{Application of Sweet Lime POD for Decolorizing Industrial Effluent}

Binding the heme group to the enzyme active site is strictly $\mathrm{pH}$ dependent, and a loss or decrease of enzyme activity at low and high $\mathrm{pH}$ was due to instability of heme binding to the enzyme active site [46-51]. Furthermore, $\mathrm{pH}$ change affects the dissociation of amino acids that are involved in substrate binding and enzyme catalysis. Therefore, optimal $\mathrm{pH}$ is essential for proper working of a biocatalyst [52-53].

The decolorization percentage was plotted as a function of $\mathrm{pH}$ and the results obtained are shown in Fig. 1. It is obvious from the data that acidic range of $\mathrm{pH}$ was most favourable for maximum decolorization of textile industry effluents. Maximum decolorization was attained at $\mathrm{pH}$ 5.0. The decrease in percentage decolorization in the alkaline medium was observed. In accordance with our findings, direct yellow 4 was excellently decolorized at $\mathrm{pH} 5.0$ by Citrus limon POD [54-55]. This study was in good agreement with [25], while in another report the best $\mathrm{pH}$ for decolorization of industrial effluent dyes by fenugreek peroxidase was also $5.0[38]$.

Temperature significantly affects the enzymecatalysed decolorization/degradation of dyes. High temperature increases the activity of the enzyme and the reaction speeds up until an optimum level, where the enzyme behaves most efficiently. The enzymatic activity starts decreasing either due to the reaction between $\mathrm{H}_{2} \mathrm{O}_{2}$ and intermediates of the enzyme's catalytic cycle or irreversible reactions between the enzyme and free radicals.

Lowering the temperature reduces the reaction rate and leads to a reduction of free radical generation, thus slowing down enzyme deactivation [56-57]. Experiments were conducted at various temperatures $\left(25-70^{\circ} \mathrm{C}\right)$ to find the suitable temperature range for significant percentage decolorization, and results are shown in Fig. 2. It is revealed in the figure that the maximum decolorization of textile effluent was obtained at $55^{\circ} \mathrm{C}$ (although an increase in temperature above optima resulted in decreased decolorization). In contrast to our results, $40^{\circ} \mathrm{C}$ was recorded to be the optimum temperature for maximum decolorization of textile carpet effluent, red (75\%), and blue $(80 \%)$ by turnip peroxidase [50], whereas crystal violet was maximally decolorized at $50^{\circ} \mathrm{C}$ by gourd peel peroxidase [58], and drimarene
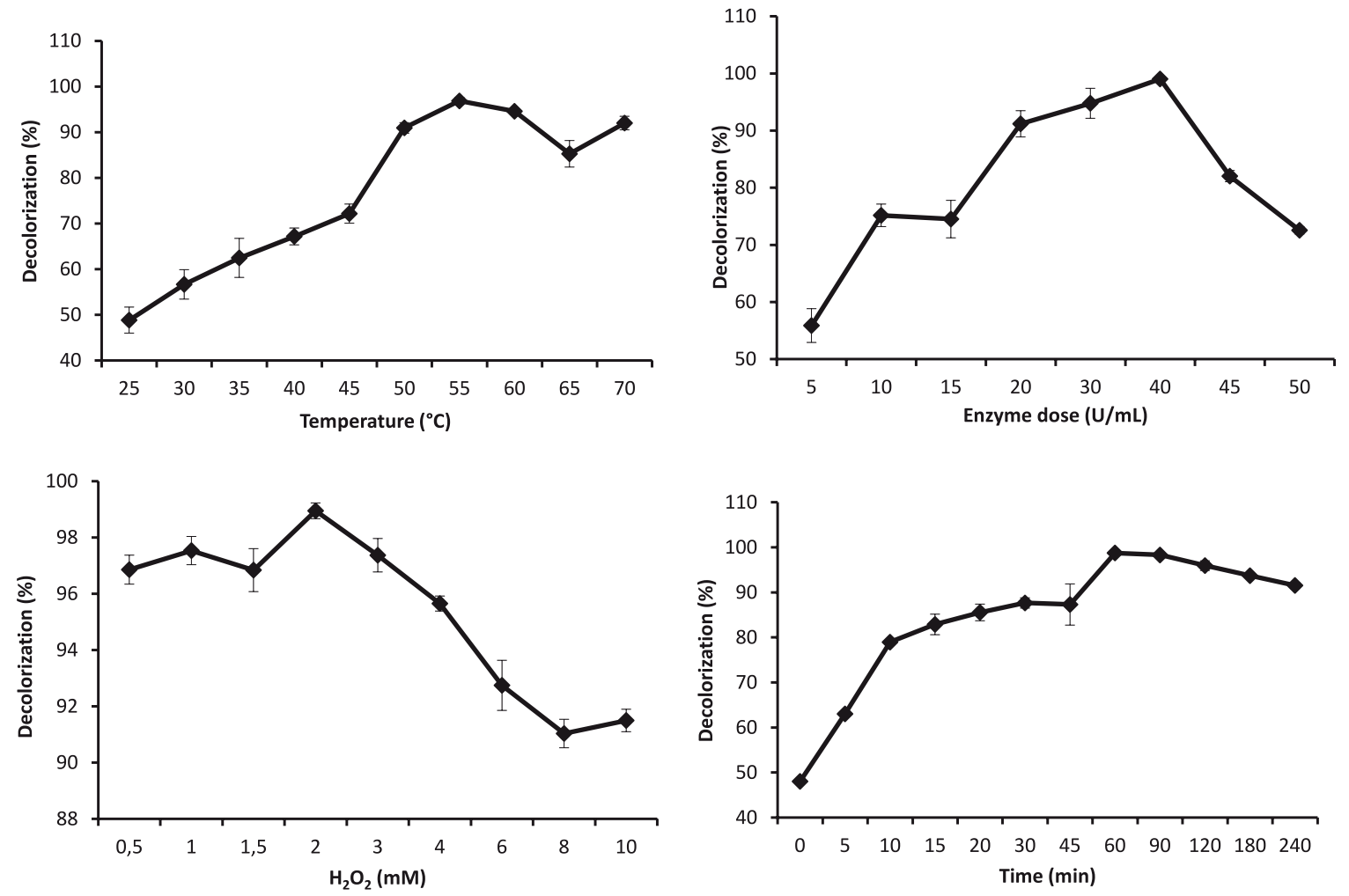

Fig. 2. Effect of temperature, enzyme dose, $\mathrm{H}_{2} \mathrm{O}_{2}$ concentration, and incubation on percentage decolourization. 
orange KGL has shown significant decolourization at $60^{\circ} \mathrm{C}[59]$.

Optimal concentration of enzymes is necessary to decolourise the effluents. Experiments were conducted by changing the enzyme dose (5.0-50.0 U/mL) and keeping other conditions constant to highlight the effect produced by enzyme dose. The results obtained are summarized in Fig. 2. We can conclude from the data that $40 \mathrm{U} / \mathrm{mL}$ of SLP was required for $99 \%$ decolorization of textile industry effluent. After the optimum, any increase in SLP did not result in an increase in percentage decolorization, i.e., saturation was attained. Similar to our previous investigation, $18 \mathrm{U} / \mathrm{mL}$ of citrus lemon peroxidase was required for almost $100 \%$ decolorization of the same effluent [35].

$\mathrm{H}_{2} \mathrm{O}_{2}$, co-substrate of POD plays its role in the catalytic mechanism of POD and thereby accepts the aromatic substrates and converts them into radicals. These radicals may polymerize or degrade into small products. Low concentration of $\mathrm{H}_{2} \mathrm{O}_{2}$ reduces the enzyme activity and high concentration can irreversibly cause enzyme inactivation [60]. The results are shown in Fig. 2.

It is said that $\mathrm{H}_{2} \mathrm{O}_{2}$ is a key factor for decolorization as depicted by the data. The efficiency of decolorization was enhanced with the increase in $\mathrm{H}_{2} \mathrm{O}_{2}$ concentration from 0.5-2.0 $\mathrm{mM}$ but slightly decreased hereafter. This might be due to the reason that $\mathrm{H}_{2} \mathrm{O}_{2}$ irreversibly oxidized the enzyme to reduce POD activity. The negative effect of high $\mathrm{H}_{2} \mathrm{O}_{2}$ concentration on decolorization efficiency was also perceived in our latest investigation for direct yellow 4 dye decolorized by Citrus limon peroxidase and GYPRA dye decolorized by Citrus reticulate var Kinnow peroxidase [54-55].

Enzyme/substrate contact time is also one of the most important parameters for decolorization of dyes by PODs. It has been reported that reaction time has a direct link to the structure of different dyes [55]. Textile industry effluent was independently incubated with SLP for increasing time period and the results thus obtained are shown in Fig. 2. It is obvious from the data that almost $99 \%$ decolorization was obtained after $60 \mathrm{~min}$ of incubation. However, after this time period no increase in percentage decolorization was recorded. In our previous investigation $100 \%$ decolorization was attained using the same effluent after 20 min by Citrus limon peroxidase [35], although in other reports much more time was required for maximum decolorization of textile effluent, e.g., $180 \mathrm{~min}$ by fenugreek peroxidase [38] and 240 min for tanning effluent by bitter gourd POD [56].

\section{Conclusions}

In this paper, efficient degradation of textile industry effluents were presented by sweet lime peroxidase. The enzyme was characterized in terms of $\mathrm{pH}$ and temperature. The enzyme showed good substrate affinity and high-activity $6,666 \mu \mathrm{mol} / \mathrm{mL} / \mathrm{min}$. Taking advantage of its activity, its potential was checked toward decolorizing textile industry effluent. SLP almost completely decolorized ( $>99 \%$ ) textile industry effluent within $60 \mathrm{~min}$ time interval at a $\mathrm{pH}$ of 5.0, temperature of $55^{\circ} \mathrm{C}, \mathrm{H}_{2} \mathrm{O}_{2}$ concentration of $2 \mathrm{mM}$, and enzyme dose of $40 \mathrm{U} / \mathrm{mL}$. The assessment of physicochemical parameters of the textile industry effluent showed decreased toxicity after treatment with SLP.

\section{Conflict of Interest}

The authors declare no conflict of interest.

\section{References}

1. CAMPOS R., KANDELBAUER A, ROBRA K.H., ARTUR C.P., GUBITZ GM. Indigo degradation with purified laccases from Trametes hirsuta and Sclerotim rolfsii. J. Biotechnol. 8, 131, 2011.

2. RIZVI F.Z., KANWAL W., FAISAL M. ChromateReducing Profile of Bacterial Strains Isolated from Industrial Effluents. Pol. J. Environ. Stud. 25 (5), 2121, 2016.

3. IQBAL M., ABBAS M., ARSHAD M., HUSSAIN T., KHAN A.U., MASOOD N., TAHIR M.A., HUSSAIN S.M., BOKHARI T.H., KHERA R.A. Gamma Radiation Treatment for Reducing Cytotoxicity and Mutagenicity in Industrial Wastewater. Pol. J. Environ. Stud. 24 (6), 2745, 2015.

4. DAA`SSI D., ZOUARI-MECHICHI H., FRIKHA F., MARTINEZ M.J., NASRI M., MECHICHI T. Decolorization of the azo dye Acid Orange 51 by laccase produced in solid culture of a newly isolated Trametes trogii strain. Biotech. 3, 115, 2013.

5. BIBI I., NAZAR N., IQBAL M., KAMAL S., NAWAZ H., NOUREN S., SAFA Y., JILANI K., SULTAN M., ATA S., REHMAN F., ABBAS M. Green and eco-friendly synthesis of cobalt-oxide nanoparticle: Characterization and photo-catalytic activity. Adv. Powder Technol. 28, 2035, 2017.

6. IQBAL M., ABBAS M., ARSHAD M., HUSSAIN T., KHAN A.U., MASOOD N., TAHIR M.A., HUSSAIN S.M., BOKHARI T.H., KHERA R.A. Gamma radiation treatment for reducing cytotoxicity and mutagenicity in industrial wastewater. Pol. J. Environ. Stud. 24, 2745, 2015.

7. IQBAL M., ALI Z., QAMAR M.A., ALI A., HUSSAIN F., ABBAS M., NISAR J. Nickel adsorption onto polyurethane ethylene and vinyl acetate sorbents. Water Sci. Technol. 76, 219,2017

8. IQBAL M., BHATTI I.A. Gamma radiation $/ \mathrm{H}_{2} \mathrm{O}_{2}$ treatment of a nonylphenol ethoxylates: degradation, cytotoxicity, and mutagenicity evaluation. J. Hazard. Mater. 299, 351, 2015.

9. IQBAL M., NISAR J. Cytotoxicity and mutagenicity evaluation of gamma radiation and hydrogen peroxide treated textile effluents using bioassays. J. Environ. Chem. Eng. 3, 1912, 2015.

10. IQBAL M., NISAR J., ADIL M., ABBAS M., RIAZ M., TAHIR M.A., YOUNUS M., SHAHID M. Mutagenicity and cytotoxicity evaluation of photo-catalytically treated petroleum refinery wastewater using an array of bioassays. Chemosphere, 168, 590, 2017. 
11. ABBAS M., ARSHAD M., NISAR N., NISAR J., GHAFFAR A., NAZIR A., TAHIR M.A., IQBAL M. Mucilage Characterization, biochemicals and enzymatic activities of laser irradiated Lagenaria Siceraria seedlings. J. Photochem. Photobiol. B: Biol. 173, 344, 2017.

12. NADEEM R., MANZOOR Q., IQBAL M., NISAR J. Biosorption of $\mathrm{Pb}$ (II) onto immobilized and native Mangifera indica waste biomass. J. Indus. Eng. Chem. 35, 185, 2016.

13. NOUREN S., BHATTI H.N., IQBAL M., BIBI I., KAMAL S., SADAF S., SULTAN M., KAUSAR A., SAFA Y. Byproduct identification and phytotoxicity of biodegraded Direct Yellow 4 dye. Chemosphere, 169, 474, 2017.

14. TAHIR N., BHATTI H.N., IQBAL M., NOREEN S. Biopolymers composites with peanut hull waste biomass and application for Crystal Violet adsorption. Int. J. Biol. Macromol. 94, 210, 2017.

15. BABARINDE A., OGUNDIPE K., SANGOSANYA K.T., AKINTOLA B.D., HASSAN A.O.E. Comparative study on the biosorption of $\mathrm{Pb}(\mathrm{II}), \mathrm{Cd}(\mathrm{II})$ and $\mathrm{Zn}(\mathrm{II})$ using Lemon grass (Cymbopogon citratus): kinetics, isotherms and thermodynamics. Chem. Int. 2, 89, 2016.

16. BABARINDE A., ONYIAOCHA G.O. Equilibrium sorption of divalent metal ions onto groundnut (Arachis hypogaea) shell: kinetics, isotherm and thermodynamics. Chem. Int. 2, 37, 2016.

17. CLARIZIA L., RUSSO D., SOMMA I.D., MAROTTA R., ANDREOZZI R. Homogeneous photo-Fenton processes at near neutral pH: A review. Appl. Cat. B: Environ. 209, 358, 2017.

18. HERNÁNDEZ-FRANCISCO E., PERAL J., BLANCOJEREZ L.M. Removal of phenolic compounds from oil refinery wastewater by electrocoagulation and Fenton/photo-Fenton processes. J. Water Proc. Eng. 19, 96, 2017.

19. KALSOOM U., ASHRAF S.S., MEETANI M.A., RAUF M.A., BHATTI H.N. Mechanistic study of diazo dye degradation by Soybean Peroxidase. Chem. Cent. J. 7, 93, 2013.

20. EL-BORAI A.M., ELTAYEB K.M., MOSTAFA A.R., ELASSAR S.A. Biodegradation of Industrial Oil-Polluted Wastewater in Egypt by Bacterial Consortium Immobilized in Different Types of Carriers. Pol. J. Environ. Stud. 25 (5), 1901, 2016.

21. COSA S., OKOH A. Bioflocculant Production by a Consortium of Two Bacterial Species and Its Potential Application in Industrial Wastewater and River Water Treatment. Pol. J. Environ. Stud. 23 (3), 689, 2014.

22. BANCI L. Structural properties of peroxidases. J. Biotechnol. 53, 253, 1997.

23. HAMID M., REHMAN K. Potential applications of peroxidases. Food Chem., 115, 1177, 2009.

24. MOHAN S.V., PRASAD K.K., RAO N.C., SHARMA P.N. Acid azo dye degradation by free and immobilized horseradish peroxidase catalyzed process. Chemosphere, 58, 1097, 2005.

25. ONDER S., CELEBI M., ALTIKATOGLU M., HATIPOGLU A., KUZU H. Decolorization of Naphthol Blue Black using the Horseradish Peroxidase. Appl. Biochem. Biotechnol. 163 (3), 433, 2011.

26. ARSLAN M. Immobilization of horseradish peroxidase on amine functionalized glycidyl methacrylate-gpoly (ethylene terephthalate) fibers for use in azo dye decolorization. Polym. Bull. 66, 865, 2011.

27. MARECIK R., BIEGAŃSKA-MARECIK R., CYPLIK P., ŁAWNICZAK L., CHRZANOWSKI L. Phytoremediation of Industrial Wastewater Containing Nitrates, Nitroglycerin, and Nitroglycol. Pol. J. Environ. Stud. 22 (3), 773, 2013

28. ALI L., ALGAITHI R., HABIB H.M., SOUKA U., RAUF M.A., ASHRAF S.S. Soybean peroxidase-mediated degradation of an azo dye- A detailed mechanistic study. BMC Biochem. 14 (1), 35, 2013.

29. BOUCHERIT N., ABOUSEOUD M., ADOUR L. Degradation of direct azo dye by Cucurbita pepo free and immobilized peroxidase. J. Environ. Sci. 25 (6), 1235, 2013.

30. GALENDE P.P., MARÍA C.G., ARELLANO J.B., ROIG M.G., SHNYROV V.L. Study on Extraction, Purification and Characterization of a Novel Peroxidase from White Spanish Broom (Cytisus multiflorus). Int. J. Plant Bio. Res. 4 (1), 1052, 2016.

31. NOUREN S., BHATTI H.N., BHATTI I.A., ASGHER M. Kinetic and thermal characterization of peroxidase from peels of Citrus reticulata Var. Kinnow. J. Animal Plant Sci. 23 (2), 430-435, 2013.

32. BRADFORD M.M. A rapid and sensitive method for the quantitation of microgram quantities of protein utilizing the principle of protein dye binding. Anal. Biochem. 72, 248, 1976.

33. LIU W., FANG J., ZHU W.M., GAO P.J. Isolation, purification and properties of the peroxidase from the hull of Glycine max var HH2. J. Sci. Food Agri. 79, 779, 1999.

34. GREENBERG A.E., CLESCERI L.S., EATON A.D. Standard Methods for the Analysis of Water and Wastewater, 17th ed., American Public Health Association (APHA), Washington, DC, 1992.

35. NOUREN S., BHATTI H.N., ILYAS S. Statistical optimization of decolorization conditions for Golden Yellow PRA by Citrus reticulata var Kinnow peroxidase and phytotoxicity evaluation of its degraded products. Desalin. Water Treat. 1-14, 2015.

36. MOHAMED S.A., EL-BADRY M.O., DREES E.A., FAHMY A.S. Properties of a Cationic Peroxidase from Citrus jambhiri cv. Adalia. Applied Biochemistry and Biotechnology, 150, 127, 2008.

37. SAT I.G. The effect of heavy metals on peroxidase from Jerusalem artichoke (Helianthus tuberosus L.) tubers. African J. Biotechnol. 7 (13), 2248, 2008.

38. HUSAIN Q. Peroxidase mediated decolorization and remediation of wastewater containing industrial dyes: a review. Rev. Environ. Sci. Biotechnol. 9, 117, 2010.

39. SARAIVA J.A., NUNES C.S., COIMBRA M.A. Purification and characterization of olive (Olea europaea L.) peroxidase - Evidence for the occurrence of a pectin binding peroxidase. Food Chem. 101, 1571, 2007.

40. CHRISTOPHER B.L., MACINNIS M.C., MACDONALD M.J., WILLIAMS J.B., SPENCER C.A., BURKE A.A., IRWIN D.J.G., D'CUNHA G.B. Purification of peroxidase from Horseradish (Armoracia rusticana) roots. J. Agri. Food chem. 58 (15), 8471, 2010.

41. MOHAMED S.A., ABULNAJA K.O., ADS A.S., KHAN J.A., KUMOSANI T.A. Characterisation of an anionic peroxidase from horseradish cv. Balady. Food Chem. 128, 725, 2011.

42. KÖKSAL E., GÜLÇIN I. Purification and characterization of peroxidase from cauliflower (Brassica oleracea L.) buds. Protein Peptide Lett. 15, 320, 2008.

43. MARZOUKI S.M., LIMAM F., SMAALI M.I., ULBER R., MARZOUK M.N. A new thermostable peroxidase from garlic Allium sativum: purification, biochemical 
properties, immobilization and use in $\mathrm{H}_{2} \mathrm{O}_{2}$ detection in milk. Appl. Biochem. Biotechnol. 127 (3), 201, 2005.

44. BHATTI H.N., JABEEN A., IQBAL M., NOREEN S., NASEEM Z. Adsorptive behavior of rice bran-based composites for malachite green dye: Isotherm, kinetic and thermodynamic studies. J. Mol. Liq. 237, 322, 2017.

45. SISECIOGLU M., GULCIN I., CANKAYA M., ATASEVER A., SEHITOGLU M.H., KAYA H.B., OZDEMIR H. Purification and characterization of peroxidase from Turkish black radish (Raphanus sativus L.). J. Med. Plants Res. 4 (12), 1187, 2010.

46. BHATTI H.N., ZAMAN Q., KAUSAR A., NOREEN S., IQBAL M. Efficient remediation of $\mathrm{Zr}(\mathrm{IV})$ using citrus peel waste biomass: Kinetic, equilibrium and thermodynamic studies. Ecol. Eng. 95, 216, 2016

47. NADEEM R., MANZOOR Q., IQBAL M., NISAR J. Biosorption of $\mathrm{Pb}$ (II) onto immobilized and native Mangifera indica waste biomass. J. Indus. Eng. Chem. 35, 185, 2016.

48. TAHIR N., BHATTI H.N., IQBAL M., NOREEN S. Biopolymers composites with peanut hull waste biomass and application for Crystal Violet adsorption. Int. J. Biol. Macromol. 94, 210, 2016.

49. BABARINDE A., OGUNDIPE K., SANGOSANYA K.T., AKINTOLA B.D., HASSAN A.O.E. Comparative study on the biosorption of $\mathrm{Pb}(\mathrm{II}), \mathrm{Cd}(\mathrm{II})$ and $\mathrm{Zn}(\mathrm{II})$ using Lemon grass (Cymbopogon citratus): kinetics, isotherms and thermodynamics, Chem. Int. 2, 89, 2016.

50. BABARINDE A., ONYIAOCHA G.O. Equilibrium sorption of divalent metal ions onto groundnut (Arachis hypogaea) shell: kinetics, isotherm and thermodynamics. Chem. Int. 2, 37, 2016.

51. BENABDALLAH N.K., HARRACHE D., MIR A., DE LA GUARDIA M., BENHACHEM F.Z. Bioaccumulation of trace metals by red alga Corallina elongata in the coast of Beni Saf, west coast, Algeria. Chem. Int. 3, 220, 2017.

52. SHINDY A. Problems and solutions in colors, dyes and pigments chemistry: A Review. Chem. Int. 3, 97, 2017.

53. SHINDY H. Basics in colors, dyes and pigments chemistry: A review. Chem. Int. 2, 29, 2016.
54. NOUREN S., BHATTI H.N., IQBAL M., BIBI I., KAMAL S., SADAF S., SULTAN M., SAFA Y. By-Product identification and phytotoxicity of biodegraded Direct Yellow 4 dye. Chemosphere, 169, 474, 2017.

55. NOUREN S., BHATTI H.N., ILYAS S., NAZLI Z.H., BIBI I., KAMAL S. Citrus limon peroxidase catalyzed decolorization of textile industry effluents and toxicological evaluation of their degraded products Fresenius Environmental Bulletin. 24 (12b), 4685, 2015b.

56. MASUDA M., SAKURAI A., SAKAKIBARA M. Effect of enzyme impurities on phenol removal by the method of polymerization and precipitation catalyzed by Coprinus cinereus peroxidase. Appl. Microbiol. Biotechnol. 57, 494, 2001.

57. BHATTI H.N., NOUREN S., ILYAS S. Recent developments in the biodegradation of synthetic dyes by plant peroxidases: A review. Environmental Science and Engineering (10 vols set). Publishers Studium Press LLC, USA. pp 383-412, 2015.

58. TABASSUM A., BHATTI H.N., NOUREN S., ZAHID M. Catalytic potential of gourd peel peroxidase for biodegradation of synthetic recalcitrant dyes Fuchsin acid and Crystal violet. J. Animal Plant Sci. 25 (3), 777, 2015.

59. HAFIZ N., BHATTI H.N., NOUREN S., MUNIR M. Decolourization of Drimarene Orange KGL by Orange (Citrus reticulata) Peroxidase. Asian J. Chem. 26, 21, 7307, 2014.

60. RYAN B.J., CAROLAN N., FAGAIN C.O. Horseradish and soybean peroxidases: Comparable tools for alternative niches. Trends Biotechnol. 24, 355, 2006.

61. JIA J., HU L., ZHENG J., ZHAI Y., YAO P., ZHAO S., SHI S., ZHAI X., ZHANG D. Environmental Toxicity Analysis and Reduction of Ceramsite Synthesis from Industrial Coal Gasification Coarse Cinder Waste. Pol. J. Environ. Stud. 26 (2), 147, 2017.

62. SIVAKUMAR S., RAMESH B., KAVITHA K., GOPALAKRISHNAN V., KANNIYAPPAN V. Bitter Gourd Peroxidase (Momordica charantia) in decolorization of Dyes from Tannery Effluent. Recent Res. Sci. Technol. 2 (2), 49, 2010. 
